\title{
ENVIRONMENTAL POLLUTION AND ITS ECOLOGICAL CONSEQUENCES ON THE NIGER DELTA: A REVIEW OF THE LITERATURE
}

\author{
Omoogun Abayomi ${ }^{1}$, Olayemi Temitope Emmanuel ${ }^{2}$ and Ogungbade Taofeek $^{3}$ \\ ${ }^{1}$ Department of Chemistry, Faculty of Science, University of Lagos. \\ Email: realestyomi@gmail.com \\ ${ }^{2}$ Department of Chemistry, Faculty of Science, University of Lagos. \\ Email: tpyemson@gmail.com \\ ${ }^{3}$ Department of Chemistry, Faculty of Science, University of Lagos. \\ Email: taohphyk@gmail.com
}

\section{Cite this article:}

Omoogun A., Olayemi T.E., Ogungbade T. (2021), Environmental Pollution and Its Ecological Consequences on the Niger Delta: A Review of the Literature. African Journal of Environment and Natural Science Research 4(4), 27-42. DOI: 10.52589/AJENSRBJGGACSV.

\section{Manuscript History \\ Received: 28 June 2021 \\ Accepted: 18 Aug 2021 \\ Published: 23 Aug 2021}

Copyright $\odot 2020$ The Author(s). This is an Open Access article distributed under the terms of Creative Commons AttributionNonCommercial-NoDerivatives 4.0 International (CC BY-NC-ND 4.0 ), which permits anyone to share, use, reproduce and redistribute in any medium, provided the original author and source are credited.
ABSTRACT: Petroleum exploration has brought a lot of revenue to the Nigerian government as most of the country's investments and expenditures depend on the profits from oil. However, the processes of petroleum exploitation over the past 60 years have also come with negative consequences most notably the environmental pollution of the Niger Delta ecosystem. Many empirical studies have been funded by partnering organizations to assess the impacts of these exploration activities on the ecosystem. This study is significant because research clearly shows that the impacts of environmental degradation affect local residents and can be felt across time and space. Our goal in this study is to synthesize the findings of those studies. Primarily, we aim to answer the following questions; 1) What are the impacts of pollution on the Niger Delta ecosystem in water, soil and air" what are the effects of oil spillage on the socio-economic activities of the people and the environment in some communities in the Niger Delta" and what are the possible processes and avenues through which these impacts can be mitigated?" Over 60 articles were systematically reviewed in this study. We reported our findings under three broad categories, focusing on the three aspects of the environment - soil, air, and water as well as the actors responsible for these acts of pollution. Our review revealed that several operating oil companies are responsible for oil spills because of mismanaged pipelines coupled with environmentally unsustainable practices of gas flaring; Conversely, illegal refining and pipeline vandalism perpetrated by militant groups of the host communities have resulted in a more polluted environment; Government negligence in regulating oil operations in the region and failure to ensure that polluted sites are adequately remediated have further compounded the crisis and environmental degradation in the region. It goes without saying that all stakeholders in the business of petroleum exploration should accept the responsibility of protecting the environment. Our review pushes this conversation further by stressing the need to involve local communities in the maintenance and monitoring of pipelines. At the end of the day, the ultimate goal of improving the quality of life of members of rural communities serves not only them but all other stakeholders.

KEYWORDS: Environment, Oil, Spillage, Soil, Water, Air 


\section{INTRODUCTION}

\section{The Niger Delta: A Geographical Introduction}

The Niger Delta region is within the Atlantic coastline stretching across the southern part of Nigeria; made up of rivers, creeks and very extensive stagnant swampy mangrove covering over $2000 \mathrm{Km}$. It has the largest Mangrove swamp in Africa and is located in the following states Abia, Akwa-Ibom, Anambra, Bayelsa, Cross River, Delta, Edo, Imo, Ondo and Rivers. The Niger Delta is classified under the tropical rain forest that is located in the north of the Delta (Ite et al., 2013; Asanebi, 2016), located between $40^{\circ} \mathrm{N}-100^{\circ} \mathrm{N}$ of the equator, It's altitude is less than $1 \mathrm{~km}$ and a mean annual rainfall is always high comparatively speaking, (Geo-JaJa et al., 2007; Asanebi, 2016). The formation of the Niger Delta is a result of the breaking away of the 4,100 km-long Niger River connecting estuaries from where it flows into the Atlantic Ocean at the Gulf of Guinea (Fagbeja et al., 2008). The Niger Delta region is situated at the apex of the Gulf of Guinea on the west coast of Africa (Doust, 1999; Haach et al., 2000; Ite, et al., 2013) and in Nigeria's South-South geopolitical zone. The Niger Delta is home to about 31 million people (Young, 2012; Ite, et al., 2013), occupies a total area of about $75,000 \mathrm{~km}$ and makes up 7.5\% of Nigeria's landmass (Ite, et al., 2013).

Henry Willink's Commission that was set up by the British Government, saw the Niger Delta region in 1958 represented by three major groups, -"Ogonis, Degema and Brass, and the western Ijaws," These geographically fall within Bayelsa, Delta and Rivers states (Asanebi, 2016). The findings of Sir Henry Willink's Commission about the region lead to the formation of the Niger Delta Basin Development Board (NDBDB) in 1961 by the first Republic Government of Nigeria (Asanebi, 2016). However, the geography of the Niger Delta region has been redefined due to the politics involved in revenue distribution from the oil profits and with the aim of accessing bigger shares of the oil revenue (Asanebi, 2016). Consequently, President Olusegun Obasanjo's government included Akwa Ibom, Abia, Cross River, Imo, Ondo and the Edo States to the core Niger Delta making it a total number of nine states in 2000 (Asanebi, 2016). 


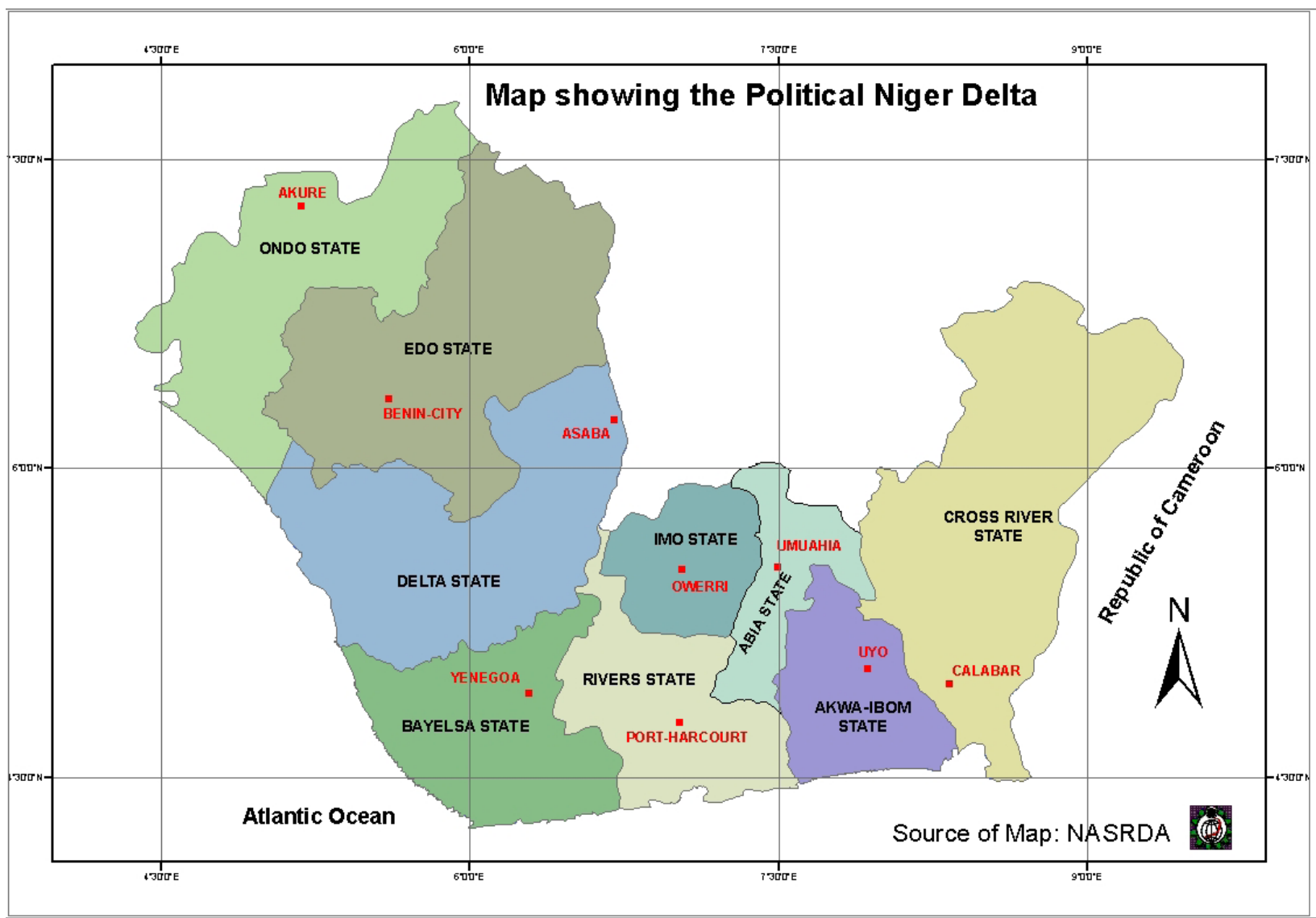

Figure 1: Map of the Niger Delta Region (Source: Ana, 2011)

\section{Complexities Associated with the Discovery of Oil in the Niger Delta}

Since the discovery of petroleum in the Niger Delta region in 1958; the region has been a source of wealth to Nigeria as a country (Bodo, 2019), and Nigeria's oil and gas reserves have been estimated to be 35.9 billion barrels and 185 trillion cubic feet respectively, quickly becoming the largest oil and gas reserves in Sub-Saharan Africa (Klett et al., 1997; Fegbeja et al., 2008). The government depends on the revenues accrued from oil for payment of all its liabilities and building assets for the nation (Bodo, 2018). In a nutshell, the Oil Industry is the pillar of Nigeria's economy, as it is responsible for 90 per cent of the country's export revenues (Bodo and David, 2018).

Oil resources have solidified Nigeria's position as the giant of Africa (Bodo, 2019). However, there had been grievances in many quarters that the other revenue streams in Nigeria had been abandoned since the discovery of petroleum (David, Bodo and Gimah, 2019). The region responsible for such wealth has been ecologically destroyed, with the locals suffering from abject poverty (Bodo and David, 2018). Petroleum exploration has raised some cogent issues such as depletion of biodiversity, coastal and riverbank erosion. Other issues include flooding, oil spillage, gas flaring, noise pollution, sewage and wastewater pollution, land degradation and soil fertility loss and deforestation, all of which are key environmental issues (Kadafa et al., 2012). This paper seeks to analyze the impact of pollution on the Niger Delta ecosystem 
under the categories of water, soil, and air respectively. Furthermore, we seek to review the effects of oil spillage on the socio-economic activities of the people and the environment in some communities in the Niger delta. Finally, we synthesize proffered possible solutions to mitigate these impacts to support the extant ideas by identifying the challenges that could be encountered in a populated environment of the Niger Delta and the links between pollution and human health. Consequently, published literature, newspapers, and other valuable materials on the Niger Delta region were reviewed extensively. Also, secondary data were sourced from published materials.

\section{Defining Pollution and its occurrence in the Niger Delta}

The ecosystem is a community of living organisms that exist with the nonliving components of their environment that share the benefits in the environment such as air, food, water and soil (Hatcher, 1990). These biotic and abiotic components are connected together through nutrient cycles and energy flows (Odum, 1971). Humans operate within ecosystems and their cumulative effects are large enough to influence external factors like climate, as the ecosystems provide a variety of goods and services upon which people depend (Schoener, 2009). Humans can pollute and destroy the ecosystem through the overuse of the available natural resources (Jones, Lawton \& Shachak, 1994). Mangroves remain very important to the Niger Delta community as well as to the various organisms that inhabit these ecosystems. Unfortunately, these oil activities have destroyed the extensive mangrove forests in the area. Apart from the illegal logging brought on by increased accessibility to forests, oil exploitation itself has depleted biodiversity, especially at ramp sites, flow stations and terminals. A lot of land degradation and forest deforestation was caused by oil-induced fire and pollution on the environment. Table 1 by Okoh and Egbon, 1999 shows the ranking of the major environmental problems in the Niger Delta.

Pollution is simply the introduction of contaminants into the natural environment that could alter the normal occurrences or distort the orderliness of the system. Pollution was also defined by the European Union 1996 Council Directive on Integrated Pollution Prevention and Control (IPPC) as "the direct or indirect introduction as a result of human activity, of substances, vibrations, heat or noise into the air, water or land which may be harmful to human health or the quality of the environment, result in damage to material property, or impair or interfere with amenities and other legitimate uses of the environment" (Fagbeja et al., 2008).

While the economic significance of hydrocarbons as the primary source of fuel and their versatile application in downstream industries are obvious, the product may also have major environmental consequences (UNEP, 1997). Oil exploration, production and processing represent prime sources of exposure to petroleum hydrocarbons. But there are other possible sources, such as vehicle and generator emissions, burning of vegetation and trash (including domestic waste), food processing and use of cooking fuels. All these activities are commonplace in Niger Delta.

In looking at the environmental consequences of hydrocarbons, it is important to remember that hydrocarbons' is an umbrella term used for hundreds of different organic compounds. Secondly, hydrocarbons can cause environmental consequences due to their chemical properties (e.g. toxicity) or physical properties (e.g. smothering). And lastly, owing to the very large number of hydrocarbons present in crude oil, the environmental and health impacts of all the constituent parts have not yet been fully studied or understood. The case of the Niger Delta 
ecosystem is even more pathetic as the majority of the people in the host communities are not knowledgeable on the consequences and implications of destroying their environment (Bodo, 2018; Gimah and Bodo, 2019a) as oil exploitation has led to massive habitat loss (Gimah and Bodo, 2019b).

\section{METHODS}

To write this article, we performed an extensive literature review. Our databases included the Niger Delta archive, Google scholar, and secondary data from the Niger Delta repository all of which were databases relevant to include in this study. We found some 90 articles online. The research team created inclusion and exclusion criteria to scope our review. For the subject matter, we sought out articles that were centred on the Niger Delta and presented data that explained the impact of this pollution on the local social-economic activities. We limited our search to articles that were published in English. Our dates of reference spanned four decades (1980 -2021). After including these inclusion and exclusion criteria, we were left with 60 articles. We also included grey literature in this review, referencing secondary data and reports published on publicly accessible websites. Ultimately, 60 articles that were later used formed the primary materials for this publication.

Our analysis plan as a research team was to read this literature using the constant comparative method (Glaser, 1965), looking for how they answered our fundamental research questions. Specifically, we investigated reports of the impact of pollution on the environment (soil, water, and air) the impact of petroleum exploration on local social-economic activities, and recommendations for mitigating these impacts. Conclusions were thematically analyzed by the research team and categorized under three aspects of the environment (air, water and land).

These findings are described in the following section below.

\section{FINDINGS AND DISCUSSION}

\section{Effects of Oil Spillage on the Socio-economic Activities in the Niger Delta}

Table 1: Ranking of Major Environmental Problems in the Niger-Delta

\begin{tabular}{|l|l|l|}
\hline Problem Type & Problem Subset & Priority Ranking \\
\hline Natural Environment & Coaster/Riverbank erosion & Moderate \\
& Flooding & High \\
& Sedimentation/Silt & Moderate \\
& Substance & Low \\
& Exotic (water hyacinth) & Low \\
\hline Development Related & Land degradation/Soil fertility & High \\
& Loss decline/ & High \\
& Agricultural & \\
& shortened fallow & High \\
& Delta forest loss(Mangrove) & High \\
& Biodiversity depletion & \\
\hline
\end{tabular}




\begin{tabular}{|l|l|l|}
\hline & Fishery Decline & High \\
& Oil spillage & High \\
& Gas flaring & Moderate \\
& Sewage and wastewater & High \\
& Other Chemical & Moderate \\
\hline
\end{tabular}

Source: Okoh and Egbon, 1999

Ipingbemi, (2009) examined the effects of oil spillage on the socio-economic activities of the people and the environment in some communities in the Niger delta and the objectives of their study were to determine the quantity of oil spills from pipelines, the area of coverage and to assess the effects of oil spillage on the people, soil and water. The soil samples from four locations and water samples from five locations were collected to determine the $\mathrm{pH}$ value of the water, also the presence and concentration of heavy metals in the soil and the total hydrocarbon content (THC) of water. The soil and water samples were analyzed using the atomic absorption spectrophotometer and gravimetric methods for soil and water, respectively. Laboratory soil analysis from sampled communities showed a higher concentration of heavy metals (chromium, lead, arsenic, etc.) above the World Health Organization (WHO) permissible levels as well as the figure for controlled s. Similarly, three of the communities studied had THC concentrations of 40,000 ppm exceeding both the WHO limit of $1 \mathrm{ppm}$ and controlled site. This has grave implications on the soil, water and socio-economic activities of the people.

\section{Soil pH}

The result of the analysis of soil samples for soil $\mathrm{pH}$ values in the Burutu local government area is shown in Table 2. The $\mathrm{pH}$ values of the spillage are higher than the controlled site. This indicates that oil spillage has increased the acidic level of the soil slightly. And the implication of these figures is that soils with a $\mathrm{pH}$ below 6.0 are more likely to be deficient in calcium, magnesium and potassium Ipingbemi, (2009). In strongly and very strongly acid soils, iron and manganese may exist in toxic quantities because of their increased solubility. In alkaline soil pH 4 7.0, manganese, zinc, iron and copper become unavailable for plant growth. It can be deduced that oil spillage has increased the acidity of soil $\mathrm{pH}$, hence depleting or proliferating some metals. These have a biological and chemical effect on biodiversity (environment) and man.

Table 2: Soil pH value analysis result.

\begin{tabular}{lc}
\hline Locations & Soil sample (pH value) \\
\hline Isiayegbene/Beniboye (Odimodi) & 6.9 \\
Okuntu & 7.1 \\
Ogulagha & 7.3 \\
Water disposal line linking Forcados terminal & 6.7 \\
Ogulagha to south point, and finally & \\
emptying into River Forcados (controlled site) & \\
\hline
\end{tabular}

Source: Ipingbemi, (2009) 


\section{Heavy Metal Analysis}

Heavy metal concentration above permissible levels has health implications. Plants can transfer heavy metal pollutants from soils into food chains and this accumulation is one of the most serious environmental concerns of the present day, not only because of the phytotoxicity of many of these metals to the crops themselves but also because of the potentially harmful effects the toxic metals have on animal and human health (Miroslav and Vladimir 1999). Using an atomic absorption spectrophotometer, the concentration of heavy metals in the different soil samples was determined as shown in Table 3.

Table 3: Heavy metal soil concentration and their permissible levels.

\begin{tabular}{|c|c|c|c|c|c|}
\hline \multirow[b]{2}{*}{$\begin{array}{l}\text { Parameter } \\
\text { (heavy metals) }\end{array}$} & \multirow[b]{2}{*}{$\begin{array}{l}\text { Permissibe } \\
\text { level by } \\
\text { WHO } \\
(\mathrm{ppm})^{\mathrm{a}}\end{array}$} & \multicolumn{4}{|c|}{ Concentrations in locations ${ }^{\mathrm{b}}$} \\
\hline & & $\begin{array}{c}\text { Isiayegbene/ } \\
\text { Beniboye } \\
\text { (Odimodi) } \\
\text { (ppm) }\end{array}$ & $\begin{array}{c}\text { Okuntu } \\
\text { (ppm) }\end{array}$ & $\begin{array}{l}\text { Ogulagha } \\
\text { (ppm) }\end{array}$ & $\begin{array}{l}\text { WDL } \\
\text { (ppm) }\end{array}$ \\
\hline Chromium & 0.05 & 0.054 & 0.27 & 0.98 & 0.00 \\
\hline Nickel & 0.02 & 0.0 & 0.0 & 1.7 & 0.9 \\
\hline Copper & 1.3 & 0.09 & 0.07 & 0.30 & 0.07 \\
\hline Cadmium & $0.005-0.03$ & 0.000 & 0.004 & 0.015 & 0.00 \\
\hline Selenium & 0.05 & 25.288 & 0.000 & 21.115 & 0.00 \\
\hline Arsenic & 0.010 & 1.8 & 1.4 & 6.9 & 0.00 \\
\hline Lead & 0.015 & 0.38 & 0.04 & 0.00 & 0.00 \\
\hline Mercury & 0.002 & 0.000 & 0.000 & 2.712 & 0.00 \\
\hline
\end{tabular}

Source: Ipingbemi, (2009)

\section{THC of Water}

The concentration of THC in water published in their studies shows that the concentrations are higher than those of the WHO standard and these high levels cannot be divorced from the impact of oil spillage.

Table 4: Gravimetric analysis of THC.

\begin{tabular}{|c|c|c|}
\hline Locations & THC $\mathrm{ppm}^{\mathrm{a}}$ & $\begin{array}{l}\text { WHO permissible level for } \\
\text { THC in ppmb }\end{array}$ \\
\hline Isiayegbene/Beniboye (Odimodi) & 40,000 & 1 \\
\hline Okuntu & 40,000 & 1 \\
\hline Ogulagha & 40,000 & 1 \\
\hline WDL & 0 & 1 \\
\hline Enekorogha(controlled environment) & 0 & 1 \\
\hline
\end{tabular}

Source: Ipingbemi, (2009) 


\section{Impacts on Soil}

Hydrocarbon pollution of soil can occur in several ways, from natural seepage of hydrocarbons in areas where petroleum is found in shallow reservoirs, to accidental spillage of crude oil on the ground. Regardless of the source of contamination, once hydrocarbons come into contact with the soil, they alter their physical and chemical properties. The degree of alteration depends on the soil type, the specific composition of the hydrocarbon spilt and the quantity spilt (UNEP 2011). Oil from the refineries is transported through pipelines that sometimes are already corroded or rusted. The leakages from the corroded pipes usually spurt over a wide area destroying crops, fish ponds, economic trees, farmlands, and biodiversity (Ugboma, 2015). It has been reported that an average of one oil spill occurs every week causing grave damage to the environment in the Niger Delta (Federal Ministry of Environment, 2006). According to Ugboma (2015), fires occasioned by the explosion of oil tankers, oil installations, and leakages from oil pipes and pipelines explosion during oil bunkering or pipeline vandalism destroys the plants, insects, birds and also burns the organic matter content of the soil. The resultant effects of land pollution lead to a reduction in agricultural activities, water supply settlement and the ecosystem or biodiversity within the region (Oronto, 1998).

Contaminated soil can affect the health of organisms through direct contact or via ingestion or inhalation of soil contaminants that have been vaporized. Soil also acts as a reservoir of residual pollution, releasing contaminants into groundwater or air over extended periods of time, often after the original source of pollution has been removed (Baker 1991). Aside from the oil spillages; previous studies also revealed that flares have negative effects on vegetation growth, animal life and ecological equilibrium in the Niger Delta area (Alakpodia, 1980, 1995; Ana, 2011). The heating up of the environment from pollution sites kills vegetation around the heated area. It suppresses the growth of flowering plants and reduces agricultural productivity and wildlife biodiversity (Ana, 2011).

\section{Impacts on Water}

Water is very essential for human survival. The challenges associated with the available water could be any of the following cases: 'too little water, too much water, and polluted water (Adebola 2001; Nduka and Orisakwe, 2011). Hydrocarbons can enter the water through direct spills or from a spill originally occurring on land and subsequently reaching water bodies through the effects of wind, rain, surface or sub-surface flow. Niger Delta region of Nigeria faces several environmental issues among which water contamination is predominant (Akpan and Ajayi, 2006; Raji \& Abejide, 2013) and even the available water is usually polluted because of environmental pollution and degradation of the area (Efe, 2001). In fact, access to safe drinking water is gradually reduced based on the activities from oil exploration and spills (Akpan and Ajayi, 2006; World Bank, 2008). Studies have revealed that there is a strong relationship between human activities and pollution of the environment (Jenkins et al. 1996).

Hydrocarbons can cause both physical and chemical effects in water; even very small quantities of hydrocarbons can prevent oxygen transfer in the water column, thus affecting aquatic lifesupport systems. The presence of mere traces of a highly toxic hydrocarbon, such as benzene, may render water unfit for human consumption (O'Reilly 2001). Nwineewii et al., 2015 examined the concentration of polycyclic aromatic hydrocarbons $(\mathrm{PAH})$ in surface water and their toxicological effect in some creeks of southeast Rivers State (Niger Delta) Nigeria. 
The result obtained from their studies shows that the concentrations of PAHs ranged between 0.008 and $0.249 \mathrm{mg} / \mathrm{l}$. From their results, it was also observed that the concentrations of the pollutants were higher than the USEPA recommended limits of between 0.20 and $400 \mathrm{ppb}$ for drinking water and some of the PAHs recorded were those that are toxic even at low concentrations and they were prominent near the point source. They concluded in their paper that the consumption of any aquatic habitat from these creeks be suspended forthwith as well as the use of the creeks for domestic purposes pending when a proper remediation exercise is carried out. In the case of the Niger Delta region, the oil exploitation in the region by multinational oil companies has led to the water contamination of the entire region and has had its toll on the environment (Nduka et al. 2008).

Oil extraction and spill as major contributors to extensive pollution of water sources in the Niger Delta (Akpan and Ajayi, 2006; UNEP, 2011; Bodo, 2019). In the Niger Delta alone, there have been more than 4,000 oil spills, discharging several million barrels of crude oil into the ponds, ditches, creeks, beaches, streams, and rivers (Amaize, 2007; Nduka and Orisakwe, 2011). Studies indicate that acid rain is widely distributed in the Niger Delta region (Agbebi 2011, Ejelonu 2011, Nduka 2010, Efe 2010.) On average, a pH value of 5.06 from a range of 4.98-5.15 (Nwankwo 2011) is usually obtained. This has had a tremendous impact on the roofs of houses, as homes with corroded roofs are commonplace within the communities. Several cases of water-borne illness are reported annually due to the effect of oil spill-related water pollution (Ana, 2011; Nwilo \& Badejo 2005; David and Bodo, 2019; David, Bodo and Gimah, 2019). To date, water pollution remains one of the major environmental public health problems arising from extensive oil operations in the region. The health of a considerable number of Ogoni residents for example has been severely impaired due to surface and underground water contamination (UNEP 2016).

\section{Impacts on Air}

Air Pollution results from the presence of one or more contaminants or pollutants in the atmosphere in a quantity above the bearable limits over a long period of time causing harm to man, animals, plants and other materials exposed in the environment (Ukpere et al., 2018). Air pollution could come into a system through natural (earthquakes, volcanic eruption, etc) or anthropogenic or manmade sources (gas flaring, bush burning, etc). Natural gas is currently mostly disposed of either by flaring or venting. Gas flaring refers to the process of burning the gas on reaching the ground surface during exploration and exploitation processes. Venting, on the other hand, involves discharging the gas into the air without burning (Emam 2016). In addition, (Emam 2016) describes flaring as the controlled combustion of unprocessable (due to technical or economic reasons) natural gas that may otherwise be sold or used. Both practices involve the atmospheric discharge of hazardous substances and are therefore environmentally unfriendly, constituting a major source of air pollution that have had very severe environmental and public health consequences in the Niger Delta.

Air pollution is now a normal occurrence and a serious environmental problem confronting the Niger Delta people. The air pollution of the region results from operations of oil industries that usually releases a barrage of substances like volatile organics, oxides of carbon, nitrogen, sulphur, particulate matter, heavy metals and other toxins at levels that exceed both the national and international standards (Ana, 2011). In the Niger Delta, the major source of air pollution is gas flaring by the operating oil companies (Bodo, 2018). Gas flaring contributed an estimated 12.7 million metric tonnes of carbon in 2004 through $\mathrm{CO}_{2}$ emissions by the oil industries in the 
Niger Delta alone (Marland et al., 2007; Fagbeja et al., 2008). Nigeria is reported to have the highest record (19.79\%) of natural gas flaring globally and is responsible for about $46 \%$ of Africa's total gas flared per tonne of oil produced (Cedigaz, 2000; Ana, 2011). Many in the region have reported a decrease in visibility due to various combustion activities by the operating oil companies that are releasing oxides of nitrogen and other lower fractions of hydrocarbons daily into the atmosphere; causing serious smog in the region (Ana, 2011).

Oluwole et al. (1996) in a typical air quality assessment of the Niger Delta showed that the levels of volatile oxides of carbon, nitrogen and sulphur and total particulates exceed existing Federal Environmental Protection Agency's (FEPA,1991) standards. Also, Olobaniyi and Efe (2007) showed elevated levels of lead at concentrations of $0.56 \mathrm{mg} / \mathrm{l}$ in the atmosphere. The daily flaring of gas in the region has led to the discharge of about 45.8 billion kilowatts of heat into the atmosphere of the Niger Delta from 1.8 billion cubic feet of gas every day (Aaron, 2006; Ana 2011). Similarly, the Fridtjof Nansen Institute (2017) and (Nriagu 2011) posit that gas flaring in the Niger Delta adds an approximate 35 million metric tons of carbon dioxide and methane, annually. The issue is further aggravated by the inefficiency of the flare systems, which leads to incomplete combustion of the gas, giving rise to the formation of various hazardous organic products such as volatile organic compounds (VOCs), polyaromatic hydrocarbons (PAHs), and several inorganic pollutants (Kostiuk 2004).

The result of this is a complex interaction of thermal pollution and air pollutants, which can give rise to further complex substances that are harmful to human and environmental health. Owing to incomplete combustion, a larger percentage of the flared gas released is methane. This has, over the decades, increased the amount of greenhouse gases (GHGs) in the atmosphere, hence increasing the global warming potential of the region. At these flared sites, temperatures are reported to be as high as $16000^{\circ} \mathrm{C}$ (Ogbuigwe, 1998). It is reported that even at an average distance of 48.8 metres from the flared sites in Isoko in Delta State, the temperature was still as high as $4000^{\circ} \mathrm{C}$ was recorded (Ogbuigwe, 1998; Ana 2011). In all cases of air pollution, it was discovered that the quantities of these emissions far exceed both local and international standards, and have had various severe health consequences (Environmental Rights Action 2016) such as asthma, respiratory difficulties, premature deaths, cancer, and miscarriages among pregnant women (UNEP 2016, Environmental Rights Action/Friends of the Earth 2016, Agency for Toxic Substances and Diseases Registry (ASTDR 2016).

Some of the health impacts are shown in Table 5.

Table 5. Some human health effects of gas flare pollutants in the Niger Delta.

\begin{tabular}{|l|l|l|}
\hline Serial No & Chemical Name & Human Health Effect \\
\hline $\mathbf{1}$ & $\begin{array}{l}\text { Alkanes: methane, } \\
\text { ethane, propane }\end{array}$ & $\begin{array}{l}\text { Low levels: This can result in swelling, itching and } \\
\text { inflammation (ASTDR 2016). } \\
\text { High levels: May cause skin infections such as eczema and } \\
\text { acute lung swelling (ASTDR 2016). }\end{array}$ \\
\hline $\mathbf{2}$ & $\begin{array}{l}\text { Alkenes: ethylene, } \\
\text { propylene }\end{array}$ & $\begin{array}{l}\text { May result in weakness, nausea and vomiting (ASTDR } \\
\text { 2016). }\end{array}$ \\
\hline $\mathbf{3}$ & BTEX & $\begin{array}{l}\text { They are toxic and are either carcinogenic or probable } \\
\text { carcinogens (ASTDR 2016). Targets on exposure are } \\
\text { usually the nervous system and blood-forming organs. }\end{array}$ \\
\hline
\end{tabular}




\begin{tabular}{|c|c|c|}
\hline 4 & Carbon monoxide & $\begin{array}{l}\text { Low levels: Can cause permanent damage to the heart and } \\
\text { brain (ASTDR 2016). May harm the mental development of } \\
\text { foetuses and children. } \\
\text { High levels: Can lead to miscarriage and death (ASTDR } \\
\text { 2016). }\end{array}$ \\
\hline 5 & Hydrogen sulphide & $\begin{array}{l}\text { Low levels: Nausea, headaches, delirium, disturbed } \\
\text { equilibrium, tremors, convulsions, and skin and eye } \\
\text { irritation (ASTDR 2016). } \\
\text { High levels: Respiratory tract and mucous membrane } \\
\text { irritation; may cause immediate or delayed pulmonary } \\
\text { oedema (ASTDR 2016). } \\
\text { May result in extremely rapid unconsciousness and death } \\
\text { (ASTDR 2016). }\end{array}$ \\
\hline 6 & $\begin{array}{l}\text { Nitrogen dioxides } \\
(\mathrm{NO}, \mathrm{NO} 2)\end{array}$ & $\begin{array}{l}\text { Cough, shortness of breath, tiredness, and nausea may also } \\
\text { occur. } \\
\text { The build-up of fluid in the lungs } 1 \text { or } 2 \text { day(s) after } \\
\text { exposure is also possible (ASTDR 2016). } \\
\text { High levels: May result in rapid burning, spasms, and } \\
\text { swelling of the upper respiratory tract and throat tissues. } \\
\text { Reduced oxygenation of body tissues, a build-up of fluid in } \\
\text { lungs. } \\
\text { Death (ASTDR 2016). }\end{array}$ \\
\hline 7 & Sulphur dioxide & $\begin{array}{l}\text { Low levels: Asthmatics are very sensitive to respiratory } \\
\text { effects (ASTDR 2016). } \\
\text { High levels: Burning sensation of the nose and throat, } \\
\text { breathing difficulties, and severe airway obstructions were } \\
\text { observed in miners exposed to a copper mine explosion } \\
\text { (Gobo et al., 2009). } \\
\text { A } 100 \text { ppm in } 100 \text { parts of air has been demonstrated to be } \\
\text { immediately dangerous to human health and life (ASTDR } \\
\text { 2016). }\end{array}$ \\
\hline
\end{tabular}



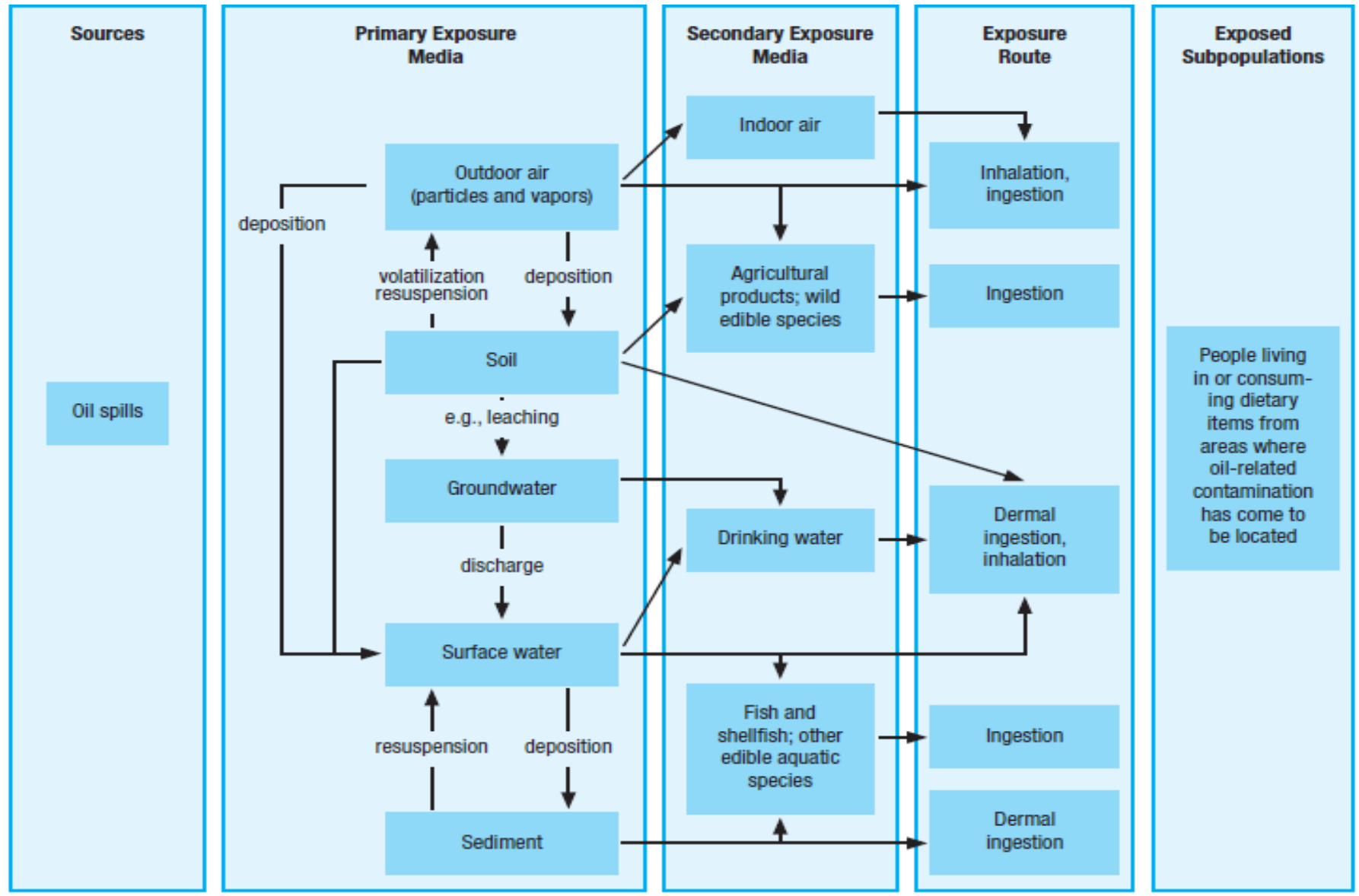

Figure 2: Conceptual model of human exposure to oil spills (Source: UNEP, 2011)

\section{CONCLUSION AND RECOMMENDATIONS}

The history of oil exploration and production in the Niger Delta is a long, complex and often painful one that to date has become seemingly intractable in terms of its resolution and future direction. It is clear from scientific investigations that oil contamination in the Niger Delta is widespread and severely impacting many components of the environment which has led to the massive environmental devastation of the Niger Delta region. The Ogoni people for example live with this pollution every minute of every day, 365 days a year. According to the World Bank data statistics published on their webs that the average life expectancy in Nigeria is less than 55 years, it is a fair assumption that most members of the current Niger Delta community have lived with chronic oil pollution throughout their lives. The devastation of the Niger Delta region has resulted in the loss of livelihood of the people as their farmlands and rivers for agricultural and fishing activities were destroyed.

All stakeholders in the oil business cannot deny their involvement or the part they played in the destruction of the Niger Delta ecosystem. In fact, the blame directly goes to the government, multinational oil companies, militant groups, political leaders and the community chiefs for the 
destruction of the Niger Delta ecosystem. Emergency measures such as ensuring that all drinking water wells where hydrocarbons were detected are marked and that people are informed of the danger. Adequate sources of drinking water to those households whose drinking water supply is impacted and also mount a public awareness campaign to warn individuals who are undertaking artisanal refining that such activities are damaging to their health and the ecosystem. Comprehensive air quality monitoring across the Niger Delta should be initiated to track ongoing pollution, to help establish guidelines for protecting public health and to track improvements at sites where clean-up activities are underway. Soil remediation at every s at which contaminant concentration in the sediment that exceeds the intervention value needs to be assessed on a case-by-case basis. Once a decision on intervention is taken, additional investigations will be needed, including analysis of the sediment for other contaminants and particle size. Only then can a final decision be made on the most appropriate clean-up technology to be used.

The multinational oil companies should ensure they carry out their Corporate Social Responsibility (CSR) diligently by providing the needed basic amenities in the host communities and accepting responsibility for every oil spill in the region by ensuring that the oil pipelines are properly monitored or policed to ensure the safety of lives and properties in their line of operation. The members (the youths, political or local leaders, traditional leaders, chiefs, youths, women) of the host communities should protect their environment against all forms of pollution by working in harmony with the operating oil companies, to create a peaceful atmosphere that is free from violence and any form of civil disturbance or civil unrest. The community members must avoid acts (like illegal oil refining, oil pipe vandalism, the bombing of flow stations, kidnapping and other vices) that further pollute their environment and put the image of members of the host community in a bad light. The government (whether at the Federal or State or Local Government level) must regulate and monitor the activities of the multinational oil companies and that of the host communities in the Niger Delta region. The government must ensure that the Niger Delta is developed at all costs. We aim to access and all necessary environmental laws and regulations are followed in the exploration of petroleum in the region.

\section{REFERENCES}

Aaron, K. K. (2006). Human rights violation and environmental degradation in the Niger Delta Region of Nigeria. Activating Human Rights, Peter Long, Oxford, Borne, New York, 193215.

Adebola, K. D. (2001). Groundwater quality in Ilorin Township: an environmental review. African Journal of Environmental Studies, 2(2), 4-6.

Agbebi, F. O. (2011). Impact of fish farming on poverty alleviation in Ekiti-State. International Journal of Science and nature, 2(3), 456-460.

Agency for Toxic Substances and Diseases Registry (ASTDR). Interaction Profile for Benzene, Toluene, Ethylbenzene and Xylene. Available online: https://www.atsdr.cdc.gov/interactionprofiles/ip-btex/ip05-c3.p (accessed on 18 December 2016).

Agency for Toxic Substances and Diseases Registry (ASTDR). Nitrogen Oxides. Available online: https://www.atsdr.cdc.gov/toxfaqs/tfacts175.pdf (accessed on 22 December 2016). 
Akpan, D., \& Ajayi, O. (2016). Adverse effect of water contamination or pollution to human health and safety in the Nigeria delta-Nigeria: an environmental case study. Journal of Environment and Earth Science, 6(10), 2224-3216.

Alakpodia, I. J. (1980). The effect of gas flaring on the microclimate and adjacent vegetation in Isoko area. Unpublished M. Sc. Thesis, University of Lagos, Nigeria.

Alakpodia, I. J. (1995), "The Oil Industry and the Economic Environment of the Niger Delta" Paper presented at the 30th Annual Conference. Nigeria Geographical Association, at the University of Benin. Benin City. Nigeria.

Amaize, E. (2007). Crises from the Creeks. Saturday vanguard newspapers (www. vangardngr. com). March, 17, 11-13.

Ana, G. R. (2011). Air pollution in the Niger Delta area: Scope, challenges and remedies. The Impact of Air Pollution on Health, Economy, Environment and Agricultural Sources, 181.

Asanebi, D. (2016). A concise view of Niger Delta Region of Nigeria: An interpretation of a Nigerian historian. International Research Journal of Interdisciplinary and Multidisciplinary Studies, 56-63.

Baker, J. M. (1991). Guidelines on biological impacts of oil pollution. IPIECA.

Bodo, T. (2018). Community understanding of the environmental and socio-economic consequences of petroleum exploitation in Ogoni, Rivers State, Nigeria. International Journal of Advanced Research and Publications, 2(11), 51-55.

Bodo, T. (2019). Deep issues behind the crisis in the Niger Delta Region: The case of oil exploration in Ogoniland, Rivers State, Nigeria. Asian Journal of Geographical Research, $1-12$.

Bodo, T., \& David, L. K. (2018). The petroleum exploitation and pollution in Ogoni, Rivers State, Nigeria: The community perspective. European Scientific Journal, 14(32), 197-212.

Bodo, T., \& Gimah, B. G. (2019). Petroleum pollution and decrease neuroplasticity in brain development of the Ogoni children in Rivers State, Nigeria. Journal of Advances in Medicine and Medical Research, 1-13.

Cedigaz, (2000) www.cedigaz.org.Central Bank of Nigeria. (2004), Statistical Bulletin 15

Doust, H. (1990). Petroleum geology of the Niger Delta. Geological Society, London, Special Publications, 50(1), 365-365.

Efe, S. I. (2001b). An appraisal of the quality of Rain and groundwater resources in Nigerian Cities. In The case of Warri Metropolis. A Ph. D Seminar Paper Presented in the Dept of Geography and Regional Planning, Delta State University Abraka (p. 119).

Efe, S. I. (2010). Spatial variation in acid and some heavy metal composition of rainwater harvesting in the oil-producing region of Nigeria. Natural hazards, 55(2), 307-319.

Ejelonu, B. C., Adeleke, B. B., Ololade, I. O., \& Adegbuyi, O. (2011). The Chemistry of Rainwater Samples Collected within Utorogu-Oil Producing Community in Niger Delta, Nigeria II. European Journal of Scientific Research, 58(2), 189-203.

Emam, E. A. (2016). Environmental pollution and measurement of gas flaring. Int. J. Innov. Res. Sci. Eng. Technol, 2, 252-262.

Environmental Rights Action/Friends of the Earth (ERA/FoE). Gas Flaring in Nigeria: A Human Rights, Environmental and Economic Monstrosity. Available online:

https://www.foe.co.uk/ss/default/files/ downloads/gas_flaring_nigeria.pdf (accessed on 27 December 2016).

Fagbeja, M. A., Chatterton, T. J., Longhurst, J. W. S., Akinyede, J. O., \& Adegoke, J. O. (2008). Air pollution and management in the Niger Delta-emerging issues. WIT Transactions on Ecology and the Environment, 116, 207-216.

Federal Environmental Protection Agency, (1991), National Policy on the Environment, The Presidency, Abuja, Nigeria 
Federal Ministry of Environment (1999). National Policy on Environment in Nigeria.

Fridtjof Nansen Institute. Gas Flaring and Global Public Goods. Available online: https://www.fni.no/ getfile.php/132146/Filer/Publikasjoner/FNI-R2001.pdf (accessed on 1 March 2017).

Geo-JaJa, M., \& Geo-JaJa, S. (2007). Poverty and Inequality in the Niger Delta: Is National Economic Empowerment and Development Strategy the Answer?. Comparative and International Education, 36(1).

Gimah, B. G., \& Bodo, T. (2019). Creation of awareness through environmental adult education as a solution to the problem of habitat loss in Ogoni, Rivers State, Nigeria. International Journal of Advanced Research and Publications, 3(1), 22-28.

Gimah, G. B., \& Bodo, T. (2019b). Curbing human activities that degrade the environment: the relevance of environmental adult education. Earth \& Environmental Science Research \& Reviews, 2(5), 1-7.

Gobo, A. E., Richard, G., \& Ubong, I. U. (2009). Health impact of gas flares on Igwuruta/Umuechem communities in Rivers State. Journal of Applied Sciences and Environmental Management, 13(3).

Haack, R. C., Sundararaman, P., Diedjomahor, J. O., Xiao, H., Gant, N. J., May, E. D., \& Kelsch, K. (2000). AAPG Memoir 73, Chapter 16: Niger Delta Petroleum Systems, Nigeria.

http://cdiac.ornl.gov/ftp/ndp030/nation.1751_2004.ems (Retrieved 10th May 2019).

https://data.worldbank.org/indicator/SP.DYN.LE00.IN?locations=NG

Hydrocarbon-Impacted Soil on Groundwater. American Petroleum Institute. 14 pp. Available at www.api.org/ehs/groundwater/upload/14_Bull.pdf

Ipingbemi, O. (2009). Socio-economic implications and environmental effects of oil spillage in some communities in the Niger delta. Journal of Integrative Environmental Sciences, 6(1), 7-23.

Ite, A. E., Ibok, U. J., M. U., \& Petters, S. W. (2013). Petroleum exploration and production: Past and present environmental issues in Nigeria's Niger Delta. American Journal of Environmental Protection, 1(4), 78-90.

Jenkins P, Southern T, Truesdale V, Jeary A (1996) Waters. In: Watts S, Halliwell L (eds) Essential environmental science. Methods and techniques. Routledge, London, pp 336-350

Jones, C. G., Lawton, J. H., \& Shachak, M. (1994). Organisms as ecosystem engineers. In Ecosystem management (pp. 130-147). Springer, New York, NY.

Kadafa, A. A., Zakaria, M. P., \& Othman, F. (2012). Oil spillage and pollution in Nigeria: organizational management and institutional framework. Journal of Environment and Earth Science, 2(4), 22-30.

Klett, T. R., Ahlbrandt, T. S., Schmoker, J. W., \& Dolton, G. L. (1997). Ranking of the world's oil and gas provinces by known petroleum volumes (No. 97-463). US Dept. of the Interior, Geological Survey.

Kostiuk, L., Johnson, M., \& Thomas, G. (2004). University Of Alberta Flare Research Project: final report November 1996-September 2004. 2.

Marland, G., Boden, T. A., \& Andres, R. J. (2005). Global, regional, and national CO2 emissions, Trends: A compendium of data on global change, Carbon Dioxide Inf. Anal. Cent., Oak Ridge Natl. Lab, US Dep. of Energy, Oak Ridge, Tennessee.

Miroslav, R., Bashkin, V., \& Bashkin, V. N. (1999). Practical environmental analysis. Royal Society of chemistry.

Nduka, J. K. C., Orisakwe, O. E., Ezenweke, L. O., Ezenwa, T. E., Chendo, M. N., \& Ezeabasili, N. G. (2008). Acid rain phenomenon in the niger delta region of Nigeria: economic, biodiversity, and public health concern. TheScientificWorldJOURNAL, 8, 811-818. 
Nduka, J. K., \& Orisakwe, O. E. (2011). Water-quality issues in the Niger Delta of Nigeria: a look at heavy metal levels and some physicochemical properties. Environmental science and pollution research, 18(2), 237-246.

Nriagu, J. (2011). Oil industry and the health of communities in the Niger Delta of Nigeria.

Nwankwo, C. N., \& Ogagarue, D. O. (2011). Effects of gas flaring on surface and ground waters in Delta State, Nigeria. Journal of Geology and Mining Research, 3(5), 131-136.

Nwilo, P. C., \& Badejo, O. T. (2005). Oil spill problems and management in the Niger Delta. In International oil spill conference (Vol. 2005, No. 1, pp. 567-570). American Petroleum Institute.

Nwineewii, J. D., \& Marcus, A. C. (2015). Polycyclic aromatic hydrocarbons (PAHs) in surface water and their toxicological effects in some creeks of South East Rivers State (Niger Delta) Nigeria. J Environ Sci Toxicol Food Technol, 9(12), 27-30.

O'Reilly, K. T., Magaw, R. I., \& Rixey, W. G. (2001). Predicting the effect of hydrocarbon and hydrocarbon-impacted soil on groundwater. Am Petrol Inst, 14.

Odum, E. P (1971). Fundamentals of Ecology (Third Ed.). New York: Saunders.

Ogbuigwe, A. (1998). Judicial activism in the enforcement of environmental regulations in the petroleum industry: Past, present and the future. In Proceedings of 1998 International Conference on the Petroleum and the Nigerian Environment (pp. 83-123).

Oil Industry International Exploration, \& Production Forum. (1997). Environmental management in oil and gas exploration and production: An overview of issues and management approaches.

Okoh, R. N., \& Egbon, P. C. (1999). Fiscal federalism and revenue allocation: The poverty of the Niger Delta. Fiscal Federalism and Nigeria's Economic Development, 405-419.

Olobaniyi, S. B., \& Efe, S. I. (2007). Comparative assessment of rainwater and groundwater quality in an oil-producing area of Nigeria: environmental and health implications. Journal of Environmental Health Research, 6(2), 111.

Oluwole, A. F., Olaniyi, H. B., Akeredolu, F. A., Ogunsola, O. J., \& Obioh, I. B. (1996, November). Impact of the petroleum industry on air quality in Nigeria. In 8th Biennial International Seminar on the Petroleum Industry and the Nigerian Environment, Port Harcourt (pp. 17-21).

Oronto, D. (1998). Geography and the Nigerian Environment. Geographical Perspective of Physical Environment.

Raji, A. O. Y., \& Abejide, T. S. (2013). An assessment of environmental problems associated with oil pollution and gas flaring in the Niger Delta region Nigeria, C. 1960s-2000. Arabian Journal of Business and Management Review (OMAN Chapter), 3(3), 48.

Schoener, T. W. (2009). "Ecological Niche". In S. A. Levin (ed.). The Princeton Guide to Ecology. Princeton: Princeton University Press. pp. 2-13.

Ukpere, D. R. T., Clifford, A. B., Ojule, E. S. C., \& Ottah, C. R. (2018). Impacts of Air Pollution in the Niger Delta Region of Nigeria. International Journal of Geography and Environmental Management, 4(4), 13-21.

Unep. (2011). Environmental assessment of Ogoniland. Background to Environmental Degradation in Ogoni Land.

Young, E. M. (2012). Food and Development. Abingdon Oxon Routledge. Eur. J. Org. Chem, 1, $30-45$. 